KS. JAN DYDUCH

Wydział Prawa Kanonicznego

Uniwersytetu Papieskiego Jana Pawła II w Krakowie

\title{
KONKORDAT POLSKI 1993 INSTRUMENTEM ZGODY NARODOWEJ
}

Treść: Wstęp. - 1. Troska o człowieka priorytetowym zadaniem Konkordatu i Konstytucji RP. - 2. Postrzeganie Kościoła i państwa oraz ich relacji w nauczaniu soborowym i Konkordacie. - 3. Dialog Kościoła i państwa. - Zakończenie.

\section{Wstęp}

Mądrość ludów, potwierdzona wieloma faktami, głosi, że „zgoda buduje - niezgoda rujnuje". Zgoda buduje rodziny, społeczeństwa, narody i ludy, a także pokój między narodami. Przeciwnie niezgoda, kłótnie, agresja, nienawiść - dzieli i niszczy. Wobec braku zgody i agresywnej rywalizacji między grupami politycznymi i innymi grupami interesów w naszej Ojczyźnie, której świadkami jesteśmy, zwłaszcza w ostatnich czasach, trzeba szukać narzędzi pojednania, pokoju i zgody narodowej. Wydaje się, że takim narzędziem jest Konkordat polski z 1993 roku. Konkordat ten, będący ugodą i porozumieniem, bardzo wysokiej rangi, między Kościołem katolickim a państwem polskim sprzyja pokojowi i zgodzie społecznej w Polsce. Daje on wytyczne i ukazuje możliwości wspólnego działania dla dobra człowieka, dla obywatela państwa polskiego. Reguluje relacje między Kościołem katolickim i państwem oparte na wzajemnym poszanowaniu oraz konstruktywnym dialogu. Jest dobrym przykładem dla innych Kościołów i wspólnot religijnych, którym zależy na rozwoju naszej wspólnej Ojczyzny. Te problemy zamierza zaprezentować niniejszy artykuł. 


\section{Troska o człowieka priorytetowym zadaniem Konkordatu i Konstytucji RP}

Konkordat polski 1993 roku podkreśla, że Stolica Apostolska i Rzeczpospolita Polska „...postanowiły zawrzeć niniejszy Konkordat, przy czym Rzeczpospolita Polska uwzględniła swe zasady konstytucyjne i ustawy, a Stolica Apostolska - dokumenty Soboru Watykańskiego II dotyczące wolności religijnej i stosunków pomiędzy Kościołem a wspólnotą polityczną oraz przepisy prawa kanonicznego..." ". Tak więc Konkordat jest oparty nie tylko na nauczaniu i wskazaniach Soboru Watykańskiego II i prawie kanonicznym, lecz także na zasadach zawartych w Konstytucji Rzeczypospolitej z 1997 roku oraz na innych jej ustawach. Podstawą postanowień Konkordatu są również zasady głoszące poszanowanie godności człowieka „... uznając, że fundamentem rozwoju wolnego i demokratycznego społeczeństwa jest poszanowanie godności osoby ludzkiej i jej praw..."2. Głoszenie godności osoby ludzkiej i jej praw jawi się zarówno w nauczaniu Vaticanum II, jak i w polskiej Konstytucji z 1997 roku.

Podstawowymi dokumentami soborowymi, które nauczają o godności osoby ludzkiej to głównie: konstytucja o Kościele w świecie współczesnym „Gaudium et spes”3 i deklaracja o wolności religijnej „Dignitatis humanae”4. Deklaracja ta głosi: „Ludzie naszych czasów stają się z dnia na dzień coraz bardziej świadomi godności osoby ludzkiej i wzrasta liczba tych, którzy domagają się, żeby ludzie cieszyli się i posługiwali w działaniu swym własnym osądem i odpowiedzialną wolnością - nieprzymuszani lecz powodowani świadomością obowiązku"5. Wydarzenia, mające miejsce w pierwszej połowie XX wieku, takie jak: straszne wojny światowe, barbarzyńskie

\footnotetext{
${ }^{1}$ Konkordat polski, 28 VII 1993, Dz. U., 23 IV 1998, nr 51, poz. 318 (=Konkordat), preambuła.

${ }^{2}$ Tamże, preambuła.

${ }^{3}$ Sobór Watykański II, Konstytucja Gaudium et spes (=KDK).

${ }^{4}$ Soвór WATYкAŃski II, Deklaracja Dignitatis humanae (=DWR).

${ }^{5}$ Tamże, n. 1.
} 
rewolucje, krwawe przewroty, niezwykle boleśnie dotknęły ludzkość oraz niewyobrażalnie zraniły i sponiewierały człowieka. Te dramatyczne i tragiczne wydarzenia sprawiły, że w ludziach rozbudziła się tęsknota, a nawet chęć walki o własną godność.

W tej sytuacji, Sobór Watykański II odczytując „znaki czasu”, nie mógł nie postawić pytania „Kim jest człowiek?”6. Odpowiadając na nie, nauczanie soborowe odwołuje się do początków historii ludzkości, do stworzenia człowieka przez Boga. Człowiek został stworzony na „obraz Boży”, będąc zdolny do poznania i pokochania swego Stwórcę. Został ustanowiony przez Niego panem nad wszystkimi stworzeniami ziemskimi, aby rządził i posługiwał się nimi, zgodnie z wolą Stwórcy. Bóg stworzył człowiek jako istotę rozumną i wolną, a także jako istotę społeczną, przeznaczoną do życia i rozwoju we wspólnocie ${ }^{7}$.

Człowiek stworzony na „obraz Boży” to podstawa i źródło jego godności. Tak więc rozumna i wolna osoba ludzka, będąca w jakimś stopniu odwzorowaniem i obrazem Boga, określa i uzasadnia godność osoby ludzkiej. Oprócz tego Stwórca obdarzył człowieka darami nadprzyrodzonymi. Godność osoby ludzkiej jawi się dopiero w całej pełni i pięknie wówczas, „...gdy weźmie się pod uwagę jej pochodzenie i przeznaczenie: stworzony przez Boga na Jego obraz i podobieństwo, odkupiony drogocenną krwią Chrystusa, człowiek został wezwany do tego by być synem w Synu, żywą świątynią Ducha świętego i jest przeznaczony do życia wiecznego w uświęcającej komunii z Bogiem"s.

W kontekście powyższych rozważań godność osoby ludzkiej pozostaje w ścisłej łączności człowieka ze swoim Stwórcą. Stąd ateizm jako system odrzucający Boga jest złem także dlatego, że chce oderwać człowieka od fundamentu jego godności. Ateizm występuje w wielorakich formach, niejednokrotnie pozoruje obronę człowieka i jego autonomii, niemniej jednak w ostatecznym rozrachunku ateizm występuje przeciw prawdziwej wartości i godności osoby ludzkiej

\footnotetext{
${ }^{6} \mathrm{KDK}, \mathrm{n} .12$.

${ }^{7}$ Por. tamże, n. 12, 14, 15.

${ }^{8}$ JAN PAWEŁ II, Adhortacja apostolska Christifideles laici, 30 XII 1988, wyd. pol., Libreria Editrice Vaticana (=Adhortacja ChL), n. 37.
} 
i powoduje jej bardzo poważny uszczerbek ${ }^{9}$. Reasumując: „Kościół utrzymuje, że uznanie Boga zupełnie nie stoi w sprzeczności z godnością, ponieważ godność ta opiera się na Bogu i w nim się wypełnia: człowiek bowiem jest stworzony przez Boga Stwórcę jako rozumny i wolny; szczególnie jednak jako dziecko jest powołany właśnie do łączności z Bogiem i do uczestniczenia w Jego szczęśliwości”"

$\mathrm{Z}$ uznania godności człowieka wynika poszanowanie fundamentalnych praw ludzkich, ich popieranie, głoszenie i obrona. Wśród nich szczególne miejsce zajmuje prawo do wolności. Wolność jest chyba współcześnie najczęściej spotykanym hasłem, jest „słowem kluczem", wypowiadanym przez polityków, działaczy społecznych, publicystów czy dziennikarzy. Nie zawsze jednak w ich ustach pojęcie to znaczy to samo. Termin wolność bardzo często występuje w dokumentach państwowych, międzynarodowych, a także kościelnych. Jawi się zarówno w dokumentach Vaticanum II, jak i w dokumentach posoborowego nauczania Kościoła. Jawi się tam ogólnie jako prawo do wolności, ale przede wszystkim szczególnie jako prawo do wolności religijnej i wolności sumienia. Prawo do wolności religijnej posiada podstawowe znaczenie dla innych praw fundamentalnych: „Cywilne i społeczne prawo do wolności religijnej dotykając najgłębszej sfery duszy staje się niejako punktem odniesienia i probierzem innych podstawowych praw"11. Słowa te napisał Jan Paweł II doświadczony brakiem wolności podczas II wojny światowej i powojennym zniewoleniem dyktatury komunistycznej. Osobiście był świadkiem smutnej rzeczywistości, iż tam gdzie deptane jest prawo do wolności religijnej, deptane są również inne prawa ludzkie. Prawo do wolności religijnej ma swoje korzenie i źródło w godności osoby ludzkiej, w godności człowieka, obdarowanego przez Stwórcę rozumną i wolną naturą. Nie jest więc to prawo pozytywne jako nadane przez jakąkolwiek władzę: świecką czy kościelną, lecz przede wszystkim prawo Boże - prawo naturalne. Prawo to powinno być przez każdą władzę proklamowane

\footnotetext{
${ }^{9}$ Por. KDK, n. 19-22.

10 Tamże, n. 22.

${ }^{11}$ Adhortacja ChL, n. 39.
} 
i ochraniane ${ }^{12}$. Sobór Watykański II proklamuje w sposób uroczysty prawo do wolności religijnej. Równocześnie je określa: „Tego rodzaju wolność polega na tym, że wszyscy ludzie powinni być wolni od przymusu ze strony czy to jednostki, czy też grup społecznych i wszelkiej władzy ludzkiej, i to przynajmniej tak, żeby nikt nie był zmuszany do działania wbrew swemu sumieniu ani nie doznawał przeszkody, gdy działa według swego sumienia - prywatnie czy publicznie, sam albo stowarzyszony z innymi - w należnych granicach" ${ }^{13}$. Nauczanie soborowe łączy ściśle wolność religijną z wolnością sumienia oraz wzywa, aby była ona uznawana przez prawodawstwa państwowe ${ }^{14}$.

Konstytucja RP z 16 VII 1997 roku uznaje i ogłasza prawo do wolności religijnej i wolności sumienia: „Każdemu zapewnia się wolność sumienia i religii"15. Konstytucja RP gwarantuje także obywatelom inne prawa i wolności. Są to: wolności i prawa osobiste; wolności i prawa polityczne; wolności i prawa ekonomiczne, socjalne i kulturalne ${ }^{16}$. Konstytucja stanowiąc prawa człowieka, podobnie jak wskazania soborowe, odwołuje się do godności człowieka: „Przyrodzona i niezbywalna godność człowieka stanowi źródło wolności i praw człowieka i obywatela. Jest ona nienaruszalna, a jej poszanowanie i ochrona jest obowiązkiem władz publicznych ${ }^{17 ”}$. Postanowienia Konkordatu zakorzenione we wskazaniach Vaticanum II wyrażają troskę o człowieka i jego prawa; podobnie czyni Konstytucja RP. Dla dobra człowieka, dla poszanowania jego godności ludzkiej i praw potrzebne jest ustanowienie właściwych i poprawnych relacji między Kościołem a państwem.

\footnotetext{
${ }^{12}$ Por. J. Krukowski, Kościół i państwo, Lublin 1993, s. 100.

${ }^{13}$ DWR, n. 2.

${ }^{14}$ Por. tamże, n. 2.

${ }^{15}$ Dziennik Ustaw, nr 78, poz. 483, art. 53.

${ }^{16}$ Por. tamże, art. 38-76.

17 Tamże, art. 30.
} 


\section{Postrzeganie Kościoła i państwa oraz ich relacji w nauczaniu soborowym i Konkordacie}

Sobór Watykański II uznał jako swoje nadrzędne zadanie odnowę Kościoła i jego struktury - accomodata renovatio. W tej sytuacji musiał postawić pytanie: „Ecclesia quid dicis de seipsa?” - Kościele co mówisz sam o sobie? Na to pytanie daje Sobór odpowiedź przede wszystkim w konstytucji dogmatycznej Kościele „Lumen gentium”. Już w pierwszych jej zdaniach naucza: „Ponieważ Kościół jest w Chrystusie jakby sakramentem, czyli znakiem i narzędziem wewnętrznego zjednoczenia z Bogiem i jedności całego rodzaju ludzkiego..." ${ }^{18}$. Tak więc Kościół posiada znamiona sakramentu - znaku i narzędzia jednoczącego ludzkość ze swoim Stwórcą, a także wyrażającego jedność.

Kościół jest nazwany także owczarnią Chrystusa, budowlą Bożą, rolą uprawną, mieszkaniem Boga, nowym miastem Jeruzalem, świętą świątynią ${ }^{19}$. Kościół stanowi wspólnotę bosko-ludzką: „Chrystus jedyny pośrednik, ustanowił swój święty Kościół, tę wspólnotę wiary, nadziei i miłości, tu na ziemi, jako widzialny organizm... Wyposażona w hierarchiczne organy społeczność i zarazem Mistyczne Ciało Chrystusa, widzialne zgromadzenie, jak i wspólnota duchowa, Kościół ziemski i Kościół bogaty w dobra niebieskie - nie mogą być pojmowane jako dwie odrębne rzeczy, lecz tworzą one jedną złożoną rzeczywistość, w której zrasta się pierwiastek ludzki i Boski"20. Wspólnota niewidzialna, nadprzyrodzona, stanowi jedną rzeczywistość ze społecznością ludzką, widzialną, która jest uchwytnym kształtem tajemnicy Kościoła ${ }^{21}$.

Kościół nadprzyrodzony i Kościół ziemski jest wspólnotą Ludu Bożego. Chrystus ustanowił nowy lud Boży jako naród święty, lud Bogu na własność przeznaczony, który jest wybranym plemieniem,

\footnotetext{
${ }^{18}$ Soвór Watykański II, Konstytucja Lumen gentium (=KK), n. 1.

${ }^{19}$ Por. tamże, n. 6.

20 Tamże, n. 8.

${ }^{21}$ Por. R. SobAŃski, Kościół - jego konstytucja i prawo w tajemnicy zbawienia., Annalecta Cracoviensia 8 [1976], s. 228.
} 
królewskim kapłaństwem i stanowi świętą wspólnotę Ludu Bożego ${ }^{22}$. Rzeczywistość Ludu Bożego charakteryzuje się dynamizmem, gdyż jest wybrany i poświęcony przez Boga, by wobec świata dawać Jemu świadectwo i budować Jego królestwo ${ }^{23}$. W nauczaniu soborowym jawi się nowy obraz Kościoła jako świętej wspólnoty Ludu Bożego, zespolonej z pierwiastka Boskiego - nadprzyrodzonego i pierwiastka ludzkiego - ziemskiego.

Nauczanie Vaticanum II rzuca nowe światło na rzeczywistość, którą stanowi państwo. Doktryna soborowa posługuje się pojęciem „państwo”, lecz wydaje się, iż częściej używa określenia „wspólnota polityczna". Obywatele jednoczą się we wspólnotę polityczną w celu coraz lepszego osiągania dobra wspólnego. Dobro wspólne jest zatem wyznacznikiem i uzasadnieniem tworzenia się wspólnoty politycznej, która jednoczy rzesze ludzi o rozmaitych poglądach. W takiej wspólnocie potrzebna jest władza, która kierowałaby wszystkich obywateli ku dobru wspólnemu. To kierowanie jawi się jako siła moralna oparta na wolności i świadomości podjętego zadania, a nie na autorytarności i przemocy ${ }^{24}$.

Wspólnota polityczna i jej władza mają swe źródło w porządku wywodzącym się od Boga: „Oczywiste jest zatem, że wspólnota polityczna i władza publiczna opierają się na naturze ludzkiej i z tego względu należą do porządku ustanowionego przez Boga, jednak ustalenie rodzaju rządu i desygnacja rządzących powinny być pozostawione wolnej woli obywateli" ${ }^{25}$. Władza państwowa i wszelkie jej instytucje winny spełniać swoje zadanie zgodnie z porządkiem prawnym, legalnie ustanowionym, jednak zawsze w granicach porządku moralnego dla osiągnięcia dobra wspólnego. Tak sprawowanej władzy obywatele zobowiązani są okazywać posłuszeństwo, zgodnie $\mathrm{z}$ sumieniem. Mają także prawo i obowiązek udziału w wolnych wy-

\footnotetext{
22 Por. KK, n. 9-10.

${ }^{23}$ Por. Yves Congar, Kościół jako Lud Boży, Concilium, Międzynarodowy Przegląd Teologiczny, 1-10 [1965/66], Poznań-Warszawa, 1968, s. 18.

${ }^{24}$ Por. KDK, n. 74.

25 Tamże, n. 74.
} 
borach takich przedstawicieli do władz wspólnoty politycznej, którzy gwarantują zachowanie porządku prawnego, opartego o porządek moralny ${ }^{26}$.

Sobór Watykański II naucza, że Kościół ma swoje własne zadania oraz kompetencje i dlatego nie utożsamia się z żadną wspólnotą polityczną i nie łączy się z żadnym systemem politycznym będąc znakiem i obrońcą transcendencji oraz godności osoby ludzkiej ${ }^{27}$. Z powyższego wynika: „Wspólnota polityczna i Kościół są każde na własnym terenie, od siebie niezależne i autonomiczne"28. Przywołaną zasadą zastąpiono dotychczasową teorię o dwóch społecznościach doskonałych, jakimi są: Kościół i państwo. Te społeczności określono jako doskonałe, gdyż posiadają samoistne cele i wszystkie środki, by je osiągnąć. Posługując się tą teorią Kościół bronił swojej autonomii i niezależności i jako równorzędny partner nawiązywał kontakty z państwami ${ }^{29}$. W świetle nauczania soborowego o Kościele i o wspólnocie politycznej oraz o ich wzajemnych relacjach przywołana teoria przestała być inspirująca w budowaniu relacji Kościół - państwo.

Relacje jawią się w nauczaniu soborowym na dwóch płaszczyznach: pierwsza to odniesienie zachodzące między państwem i wiernymi jako obywatelami, gdy podejmują działalność we własnym imieniu indywidualnie lub w stowarzyszeniach, kierując się chrześcijańskim sumieniem; druga to relacje między Kościołem i państwem jako dwiema odrębnymi wspólnotami ${ }^{30}$. W nauczaniu soborowym można wyodrębnić następujące zasady regulujące stosunki Kościół państwo: 1. Uznanie we współczesnych państwach faktu pluralizmu światopoglądowego; 2 . Zasada wolności religijnej zarówno w wymiarze indywidualnym, jak i społecznym, mogąca być ograniczona zachowaniem ładu i porządku społecznego oraz moralności publicznej;

\footnotetext{
${ }^{26}$ Por. tamże, n. 74-75.

${ }^{27}$ Por. tamże, n. 76.

${ }^{28}$ Tamże, n. 76.

${ }^{29}$ Por. F. BĄczkowicz, Prawo Kanoniczne, t. I, wyd. III, Opole 1957, s. 104-108.

${ }^{30}$ Por. KDK, n. 76.
} 
3. Zasada autonomii i wzajemnej niezależności Kościoła i państwa; 4. Zasada współpracy między Kościołem a państwem ${ }^{31}$.

Ukazany w nauczaniu soborowym obraz Kościoła i państwa oraz ich relacji znajduje odzwierciedlenie w Konkordacie polskim: „Rzeczpospolita Polska i Stolica Apostolska potwierdzają, że państwo i Kościół katolicki - każde w swej dziedzinie - niezależne i autonomiczne oraz zobowiązują się do pełnego poszanowania tej zasady we wzajemnych stosunkach i we współdziałaniu dla rozwoju człowieka i dobra wspólnego"32. Ta niezależność i autonomia znajdują swój wyraz w uznaniu przez państwo polskie osobowości prawnej Kościoła katolickiego ${ }^{33}$. Konsekwencją powyższych założeń jest zapewnienie państwa o swobodnym spełnianiu misji przez Kościół katolicki i wykonywaniu jego jurysdykcji zgodnie z prawem kanonicznym ${ }^{34}$.

Warto dodać, iż ustalenia Konkordatu dotyczą relacji państwa polskiego z Kościołem katolickim. Trzeba jednak zaznaczyć, iż, w pewnym sensie, na rozwiązaniach konkordatowych, skorzystały także inne Kościoły i związki wyznaniowe. Mówił o tym premier Rządu Polskiego prof. Jerzy Buzek podczas wymiany dokumentów ratyfikacyjnych Konkordatu: „Jestem przekonany, że Konkordat stwarza nieskrępowane możliwości działania dla Kościoła katolickiego w Polsce - a pośrednio tworzy je również dla innych Kościołów i wyznań" ${ }^{35}$. Istotnie z ustaleń konkordatowych zaczerpnęły inne Kościoły i wyznania w Polsce i w formie ustaw państwowych przez nie postulowanych, zapewniły sobie swobodę działalności religijnej. To zagadnienie wymaga odrębnego omówienia.

Zasada autonomii i suwerenności Kościołów i wspólnot religijnych jawi się także w Konstytucji RP: „Stosunki między państwem

\footnotetext{
${ }^{31}$ Por. R. SobAński, Jak zaczyn i niejako dusza społeczności ludzkiej, (Obecność jako zasada stosunku Kościoła do państwa), Prawo Kanoniczne, 25 (1982) nr 1-2, s. 32 .

${ }^{32}$ Konkordat, art. 1.

${ }^{33}$ Por. tamże, art. 4.

${ }^{34}$ Por. tamże, art. 5.

${ }^{35}$ Przemówienie, 25 III 1998, w: Konkordat 1993. Dar i zadanie dla Kościoła i Polski, red. J. Dyduch, Kraków 1998, s. 150.
} 
a Kościołami i innymi związkami wyznaniowymi są kształtowane na zasadach poszanowania ich autonomii oraz wzajemnej niezależności każdego w swoim zakresie, jak również współdziałania dla dobra człowieka i dobra wspólnego"36.

\section{Dialog Kościoła i państwa}

Soborowa odnowa Kościoła była nastawiona także na jego dialog ze światem współczesnym. Mówi o tym konstytucja apostolska o Kościele w świecie współczesnym już we wstępie: „Dlatego Sobór Watykański II... kieruje swoje przesłanie nie tylko do samych dzieci Kościoła i wszystkich, którzy wzywają imienia Chrystusa, lecz także do wszystkich ludzi, pragnąc wyjaśnić wszystkim, w jaki sposób pojmuje obecność i działalność Kościoła w świecie współczesnym ${ }^{37 ”}$. Odnowiony Kościół chce prowadzić dialog z odnowionym światem współczesnym. Nauczanie soborowe prezentuje program odnowy świata. Jego istota polega na tym, aby Boży plan zbawienia coraz bardziej rozszerzał się na wszystkich ludzi, wszystkich czasów i wszystkich miejsc na ziemi. Ten program odnowy winien być realizowany według zasad ewangelicznych. Jego głównymi wykonawcami są wierni świeccy współpracujący ze swymi pasterzami. Szczególnym zadaniem wiernych świeckich jest tak pokierować sprawami doczesnymi, aby służyły odnowie świata dokonywanej w duchu Ewangelii ${ }^{38}$.

Świat został stworzony przez Boga i oddany człowiekowi, aby nad nim panował: „...abyście zaludniali ziemię i czynili ją sobie poddaną..." (Rdz 1,28). Nowy program odnowy porządku doczesnego zaprezentował Jezus Chrystus przez swoją działalność, a zwłaszcza przez dzieło odkupienia. Świat ludzi, cała rodzina ludzka, stworzona przez Boga, odkupiona przez Chrystusa, zachowywana dzięki miłości Stworzyciela mają przeobrażać się zgodnie z zamierzeniem Boga. Bóg

\footnotetext{
${ }^{36}$ Art. 25, u. 3.

${ }^{37} \mathrm{KDK}, \mathrm{n} .2$.

${ }^{38}$ Por. KK, n. 30-35.
} 
nadał rodzinie ludzkiej zasady rozwoju i kierunki odnowy porządku doczesnego w perspektywie dzieła zbawczego Chrystusa ${ }^{39}$.

Określają one porządek świecki. Dlatego w rozumieniu Soboru Watykańskiego II „świeckość” oznacza udział w stwórczej działalności Boga i realizowanie planu odnowy porządku doczesnego według zasad Ewangelii. Idąc po tej linii naucza Jan Paweł II: „Kościół, jak mówi Paweł VI, posiada autentyczny wymiar świecki, ściśle związany $\mathrm{z}$ jego naturą i misją, który wywodzi się z tajemnicy Słowa Wcielonego i który realizuje się na różne sposoby w życiu członków Kościoła”40. Tak pojęta „świeckość” nie ma nic wspólnego z laicyzacją, laicyzmem, sekularyzmem i zeświecczeniem, które są tendencjami negatywnymi i zagrażają prawdziwej odnowie współczesnego świata.

Szczególnym wyrazem dialogu Kościoła ze światem współczesnym jest dialog z państwami. Niektóre państwa określają się jako „świeckie”. Nierzadko określenie to oznacza nastawienie nieprzyjazne, a nawet wrogie wobec Kościoła katolickiego. Wówczas dialog Kościoła z tak pojętym państwem „świeckim” jest utrudniony. Kościół chce prowadzić z państwami przyjazny dialog, a ten charakteryzuje się owocną współpracą. Jednak zarówno wspólnota polityczna jak i Kościół, choć z różnego tytułu służą osobistemu i społecznemu powołaniu tych samych ludzi. Służbę tę będą mogły wymienione wspólnoty pełnić dla dobra wszystkich tym skuteczniej, im bardziej prowadzić będą ze sobą zdrową współpracę, uwzględniając także okoliczności miejsca i czasu ${ }^{41}$. Przypomnijmy: „Taką współpracę deklaruje zarówno Konkordat ${ }^{42}$, jak i Konstytucja RP ${ }^{43}$ ". Takiej współpracy nie służy formuła rozdziału Kościoła i państwa. Formuła ta jest bardzo ogólna, dlatego może wyrażać się w różnych modelach i rozwiązaniach praktycznych. Jednym $\mathrm{z}$ takich modeli jest „model amerykański”, który gwarantuje wspólnotom religijnym,

\footnotetext{
${ }^{39}$ KK, n. 36; KDK, n. 2-3.

${ }^{40}$ Adhortacja ChL, n. 15.

${ }^{41}$ Por. KDK, n. 76.

${ }^{42}$ Por. Konkordat, art. 1.

${ }^{43}$ Por. Konstytucja RP, art. 25.
} 
w tym Kościołowi katolickiemu, możliwość swobodnego działania. Natomiast tzw. „model sowiecki”, na którym bazowała Konstytucja PRL, przeciwnie - dopuszczał praktycznie prześladowanie Kościołów, w szczególności Kościoła katolickiego. W nauczaniu soborowym nie ma wzmianki o rozdziale Kościoła i państwa. W oparciu o wskazania soborowe należy uznać, iż formuła ta jest błędna. Dlatego kierując się doktryną Vaticanum II można mówić jedynie o odrębności funkcji spełnianych przez Kościół i państwo. Natomiast zasada rozdziału Kościoła i państwa została w doktrynie Kościoła odrzucona jako błędna, zaś ocena konkretnych form tego rozdziału jest zróżnicowana w zależności od konkretnych działań państwa i jego prawodawstwa ${ }^{44}$.

Jak już wspominaliśmy zarówno w Konkordacie polskim 1993, jak i w Konstytucji RP z 1997 nie ma mowy o rozdziale Kościoła i państwa polskiego. Jest natomiast mowa o współpracy i współdziałaniu dla dobra wspólnego i dobra ludzi, którzy są jednocześnie katolikami i obywatelami państwa. Taka współpraca jawi się, między innymi, w formule „małżeństwa konkordatowego”, która szanuje zarówno prawo Kościoła, jak i prawo państwa polskiego ${ }^{45}$.

W dialogu Kościoła i państwa swoistą rolę pełnią wierni świeccy, a inne zadania przypadają duchownym. Wierni świeccy uczestniczą w działalności politycznej, która ma za cel zdobycie i sprawowanie władzy w państwie, a także ustanawianie porządku prawnego. Kościół uważa takie działania za godne uznania i pochwały, jeśli dokonywane są zgodnie z porządkiem moralnym ${ }^{46}$. W podejmowaniu tej działalności świeccy mają zapewnioną wolność i autonomię: „Chrześcijanie świeccy mają prawo, aby w zakresie spraw społeczności doczesnej przyznano im wolność przysługującą wszystkim obywatelom. Korzystając wszakże z tej wolności niech zatroszczą się o to, ażeby swoją działalność przeniknąć duchem ewangelicznym i mieć na uwadze naukę przedstawioną przez Urząd Nauczycielski Kościoła oraz wystrzegać się przedstawiania w kwestiach, w których mogą

\footnotetext{
${ }^{44}$ Por. J. Krukowski, Kościół i państwo, Lublin 1993, s. 54.

${ }^{45}$ Por. Konkordat, art. 10.

${ }^{46}$ Por. KDK, n. 75.
} 
być różne opinie, swojego stanowiska jako nauki Kościoła” (kan. 227 KPK). W korzystaniu z wolności w działalności politycznej, wierni świeccy mają pamiętać, iż porządek spraw doczesnych podlega prawu Bożemu ${ }^{47}$.

W sprawowaniu władzy politycznej udział duchownych jest ograniczony. Nie mogą oni brać czynnego udziału w działalności partii politycznych i w sprawowaniu władzy państwowej, chyba że w szczególnych okolicznościach - będzie wymagała tego obrona praw Kościoła i rozwój dobra wspólnego, co ocenia kompetentna władza kościelna (por. kan. 287 par. 2 KPK). Powyższy zakaz nie dotyczy diakonów stałych, którzy także są duchownymi (por. kan. 288 KPK). Trzeba zauważyć, że zakaz udziału duchownych w sprawowaniu władzy państwowej jest pochodzenia kościelnego i dlatego nie zawsze posiada bezwzględny charakter. Wskazuje także na to historia Kościoła. Powyższe rozwiązanie nie przeszkadza współpracy Kościoła z państwem, wprost przeciwnie ją umacnia.

\section{Zakończenie}

Konkordat polski z 1993 wyraża troskę o dobro obywateli polskich. Reguluje stosunki między Kościołem katolickim i państwem polskim opierając je o wzajemne poszanowanie i owocny dialog. $Z$ tej racji może stać się narzędziem zgody narodowej i pokoju społecznego w naszej Ojczyźnie. Stąd, tu i ówdzie, podnoszące się głosy o odrzuceniu Konkordatu, zagrażają dobru społecznemu i pokojowi w Polsce. Nie ma również potrzeby zmiany Konkordatu, gdyż przewiduje on ustanowienie specjalnych instytucji państwowo-kościelnych, które zajmą się rozwiązywaniem nowych problemów (por. art. 22, 25, 27).

\section{Polish Concordat 1993 as an instrument of national consensus}

Polish Concordat of 1993 takes into consideration principles of Polish Constitution and Polish laws, as well as the teaching of the Second Vatican

\footnotetext{
${ }^{47}$ Por. J. Dyduch, Obowiązki i prawa wiernych chrześcijan świeckich, w: Komentarz do Kodeksu Prawa Kanonicznego, red. J. Krukowski, Poznań 2005, s. 47-48.
} 
Council and the norms of canon law. The central ideas of Concordat are as follows: autonomy, sovereignty of the Catholic Church and Polish Sate and their mutual cooperation. Due to the fact that there is similarity of principles between Concordat and Polish Constitution, the first document in question can create a national consensus and social peace in Poland.

SŁOWA KLUCzOWE: godność człowieka, wolność, autonomia, suwerenność, dialog, Kościół, państwo

KEY WORDS: dignity of man, freedom, autonomy, sovereignty, dialog, Church, state

\section{Nota o Autorze:}

Ks. PROF. DR HAB. JAN DYDUCH - w latach 2004-2009 rektor Papieskiej Akademii Teologicznej w Krakowie, a od 2009 do 2010 Uniwersytetu Papieskiego Jana Pawła II, profesor zwyczajny kierownik Katedry Prawa Osobowego i Ustroju Kościoła na Wydziale Prawa Kanonicznego UPJPII. 